\title{
FRENCH ADMINISTRATIVE LAW
}

\author{
JAMES W. GARNER
}

I

THE FRENCH AND ANGLO-AMERICAN SYSTEMS DISTINGUISHED

The existence in France of a body of administrative law (le droit administratif), separate and distinct from the civil law, dealing, in the main, with the competence of the administrative authorities and regulating their relations with one another and with private individuals, together with a separate and distinct body of tribunals charged with deciding controversies between the administration and private persons and of resolving conflicts of competence between the administrative and the civil courts, distinguishes fundamentally the administrative and legal system of France from that of Anglo-Saxon countries. In these latter countries there are, to be sure, well settled rules of law and practice regarding the competence of the administrative authorities, the relations between them and private individuals and as to the responsibility of the State and its agents for injuries to private persons, but they do not constitute in their ensemble a separate and distinct body of law as the French droit administratif does. Dicey even goes to the length of asserting that the French droit administratif and the very principles on which it rests are quite unknown to English and American judges and lawyers. ${ }^{2}$ He does not, of course, deny the existence in America and England of administrative law but rather the French conception of it as a body of "official" law, entirely distinct and separate from the rest of the public law, based on different principles from those which determine the relations between private individuals, and applied by a special class of tribunals distinct from the ordinary civil courts. ${ }^{2}$ Dicey emphasizes the fact that in these latter countries public officials from the highest to the lowest are subject to the same law which governs private individuals that is the "ordinary law of the land"; that they are subject to the same responsibility as are private individuals, for the injuries which their official or unofficial acts may cause to others and that this responsibility is enforceable in the ordinary civil or criminal courts by a suit against the official committing the wrong. In the main this is a true statement but it is not entirely so. In fact there is no country in

${ }^{1}$ Law of the Constitution (2d ed. 1880) 182.

${ }^{2}$ See also his article, The Droit Administratif in Modern French Law (1901) I7 L. QUART. REv. 302 ff. Compare also I Goodnow, Comparative Administrative Law (I903) 6; 2 Redliçh and Hurst, English Local Government (I903) 365; Ashley, Lacal and Central Government (1906) ch. 8; Sidgwick, Elements of Politics (1897) 505-507; 2 Lowell, The Government of England (1908) 490; I Lowell, Governmexts and Parties in Central Europe (1897) 55. 
which a private individual is treated as if he were on an absolutely equal footing with the State, ${ }^{3}$ where the rights, privileges and prerogatives of public officials are wholly determined by the same law as that which determines the rights of individuals ${ }^{4}$ or where a public officer may be sued by a private individual without restriction. ${ }^{5}$ It may be added that there are in both England and the United States various claims courts, commissions, boards and departments which exercise quasi-judicial powers and which frequently decide controversies between private individuals and the government, settle claims, award compensation for damages, determine disputes relative to the powers and duties of local authorities and the like. ${ }^{b}$ These bodies bear some resemblance to the French administrative courts as regards the nature of their jurisdiction, their organization, their methods of procedure and in being what Dicey calls "extraordinary official" courts for the administration of "official" law. It is not entirely correct therefore to say that the French notion of administrative law is alien to the spirit and traditions of American and English institutions and to English and American practice.

Another striking difference between the French droit administratif and the administrative law of Anglo-Saxon countries, so far as there is any, is that the former is almost entirely jurisprudential (to employ a French term); that is to say, it is case law. ${ }^{8}$ It is largely the work of the council of state (the supreme administrative court of France), of the tribunal of conflicts (a special tribunal for deciding conflicts of competence between the civil and administrative courts) and to some extent of the court of cassation (the supreme judicial court of France). In this respect it bears a striking resemblance to the common law of England and the United States. Even those who like Dicey have criticized the French system of administrative law as fundamentally wrong have expressed their admiration for the skill and ingenuity which the council of state, in particular, has shown in building up from year to year a vast system of jurisprudence ${ }^{9}$ and in devising new remedies for

\footnotetext{
"I Goodnow, op. cit. Ir, I2.

"Compare Parker, State and Official Liability (r906) I9 HARv. L. REv. 335, 337, 339.

${ }^{5}$ Compare, for example, the English Public Authorities Protection Act of 1893 ( $56 \& 57$ Vict. c. 6r), which penalizes by the imposition of costs the individual whose suit against a public officer is unsuccessful. This and other provisions of the Act indicate a growing feeling in England that public officers should be given a larger protection against vexatious and unfounded damage suits by private persons; in short, that it is impossible to leave the individual on an equal footing with public officers when he is dealing with the State.

'As to the United States, see Pillsbury, Administrative Tribunals (I923) $3^{6}$ HARv. L. Rev. $405 \mathrm{ff}, 583 \mathrm{ff}$. As to England, compare Ashley, op. cit. 306, and 2 Redlich and Hurst, op. cit. 365 .

${ }^{2}$ Compare Parker, op. cit. 337.

'This fact constitutes one of the grounds of Dicey's criticism of the whole system of the droit administratif. $O p$. cit. I8g.

"I use the term "jurisprudence" throughout this article in the French sense as descriptive of the body of case law built up by the courts.
} 
the protection of private individuals against the arbitrary and illegal conduct of the administrative authorities. $\mathrm{He}$ even admits that the system has certain merits which Englishmen do not always recognize.

I venture to say from a somewhat extensive study of the jurisprudence of the council of state that the system of administrative law which has been slowly built up, in the main, by its decisions deserves more admiration than has ever been bestowed upon it by English and American jurists, not merely because it is in itself a monument of judicial construction but because of its extremely progressive and liberal character. It can now be said without possibility of contradiction that there is no other country where the rights of private individuals are so well protected against the arbitrariness, the abuses and the illegal conduct of the administrative authorities and where they are so sure of receiving reparation for injuries sustained on account of such conduct. This is virtually the unanimous opinion of French jurists and writers on administrative law and it is entirely justified. The council of state, which has come to be regarded as the principal guardian and protector of the rights and liberties of the people against a bureaucratic and highly centralized administration, occupies a place in the public esteem and confidence of the French which is higher even than that which the Supreme Court of the United States enjoys among the American people. It enjoys greater public confidence than the court of cassation or the inferior judicial courts because it has shown more solicitude for upholding the rights of individuals in their controversies with the government, ${ }^{10}$ its decisions are more often based upon equity, its jurisprudence has been more liberal and progressive especially in devising remedies for the protection of the individual against illegal or arbitrary administrative conduct and because recourse to it is simpler and less expensive.11 For these reasons whenever the individual has a choice he will usually bring his action before the council of state rather than before a civil court.

\footnotetext{
${ }^{10}$ It is necessary to remark in this connection that the administrative courts do not have jurisdiction over all controversies between the administration and private individuals; that is, not all of the contentienx administratif has been reserved to them. A good part of it in fact is exercised by the judicial courts. The separation between "administration" and "justice," although a fundamental principle of French law, is not therefore complete. Thus the judicial courts have jurisdiction of controversies in cases of damages resulting from the personal fault of the administrative agent, cases of expropriation, acts relating to the management of the public domain, the application of police ordinances and those relative to the petite voirie, claims against the postal administration, compensation for damages sustained by certain State employés on account of labor accidents, etc. Formerly also when the distinction between so-called "acts of authority" or "acts of gestion" was maintained, the judicial courts had jurisdiction over claims for reparation growing out of acts of the former class.

${ }^{11}$ Compare to this effect Hauriou (Précis de Droit Adninistratif et de Droit Public [1oth ed. I921] 87I, note 2) who remarks that the judicial courts "push to excess the prerogatives of the administration" (see the examples cited by him) and Duguit, (Les Transformations dik Droit Public [1913] 169) who says the
} 


\section{II}

JUDICIAL CONTROL OVER ADMINISTRATIVE ORDINANCES

A study of the history of French administrative law during the last hundred years will show that its development has consisted principally in the working out of remedies for the protection of private individuals against the arbitrary and illegal conduct of the administrative authorities and in the extension of the control of the administrative courts (particularly the council of state) over the acts of these latter authorities. It may be remarked, however, at the outset that the judicial courts also exercise a limited control over administrative conduct. This control is known as l'exception d'illégalité, by means of which the inferior judicial courts refuse to impose fines for the violation of illegal administrative ordinances. ${ }^{12}$ It is somewhat analogous to the power of American courts to refuse to enforce unconstitutional acts of the legislature. This control has gone through a very interesting process of development. During the early years of the First Empire when the judicial courts were, in large measure, the servile instruments of Napoleon, they refused to entertain the plea of illegality as a bar to prosecution for the violation of all acts of the administrative authorities, from the lowest to the highest. In I8Io, however, the court of cassation which three years before had held that the inferior judges had no right to refuse to enforce prefectoral or municipal police ordinances on the ground of their illegality, changed its opinion and ruled that they were not bound to impose fines for the violation of such ordinances. During the period of the Restoration when the judges became more independent in consequence of the adoption of the rule of irremovability, they went further and held that they were not even bound to impose fines for the violation of ordinances issued by the King, ${ }^{13}$ excep-

judicial courts, even the highest, still show a sort of superstitious fear of the administration; that they are inclined to regard an administrative act as a chose sacrée, that suitors have little confidence in them when the issue involves administrative questions, and that they look to the council of state rather than the court of cassation as the better protector of the rights of the individual against the arbitrariness of the administration. Compare also Duquesnel, Jurisprudence Comparée du Conseil d'Etat et de la Cour de Cassation (Igi2) I52-3 and Couzinet, Etude sur la Responsabilité des Groupements Administratifs (I9II) 277, both of whom point out that the judicial courts more frequently sustain the claims of the administration, whereas the council of state pronounces more often in favor of the victims of administrative misconduct. American writers who are familiar with the jurisprudence of the two Supreme Courts also admit that the rights of the individual are better protected by the council of state than by the court of cassation. Compare Parker, The Law of the Constitution (1909) 3 AMrr. PoL. Scr. REv. 363 and 2 Goodnow, op. cit. 23I.

${ }^{21}$ Appeal lies from the decision of the inferior judge in such cases to the court of cassation, for he too may commit excess of power by declaring an illegal ordinance to be legal and by condemning the violator of it. Compare Cartault, $D e$ L'Excès de Pouvoir à la Cour de Cassation (IgII) 56.

${ }^{18}$ Their decisions were sustained by the court of cassation. 
tion being made only of those which were required to be submitted by the Crown to the council of state for its advice (so called règlements d'administration publique). Over this latter class of ordinances neither the judicial nor the administrative courts exercised any control throughout the whole of the nineteenth century.

Prior to 1832 the competence of the judges in this matter was not fixed by positive law but in that year section 15 of article $47 \mathrm{I}$ of the penal code was revised and express provision was made for the punishment by fine of persons found guilty of violating ordinances (règlements) legally made. The addition of the last two words removed whatever doubt that had formerly existed regarding the right of the courts to refuse to impose fines for the violation of illegal ordinances and consequently to decide whether they were legal or illegal. The definite acceptance of this form of judicial control over the administrative authorities constituted an exception to the principle laid down by the legislation of the Revolutionary period (notably the law of I790) and subsequently embodied in the penal code (Act 127 ), that the judges should not interfere with the conduct of the administrative authorities. As the rule is now interpreted, the judicial courts may pass upon the legality of nearly every administrative act for the violation of which a fine is prescribed, and illegality includes not merely nonconformity to the laws but also incompetence, vice of form, violation of the principle of equality of citizens, of personal liberty, liberty of conscience, inviolability of domicile, violation of property rights, etc. ${ }^{14}$ Even so-called ordinances of public administration issued by the President of the Republic upon the advice of the council of state, which until Ig07 could not be questioned either before the administrative or judicial courts, are now attackable before both classes of courts on the ground of illegality and during the world war, when the French Parliament delegated extraordinary ordinance power to the President, the judicial courts regularly entertained the exception of illegality against such ordinances..$^{15}$

This power of the judicial courts to declare illegal the ordinances of the administrative authorities is, as Hauriou remarks, one of the "correc-

\footnotetext{
${ }^{11}$ Réglade, L'Exception d'Illégalité en France (r923) 40 Revue du Drort PUBLIC et de la Science Politique, 393 ff, hereafter cited as R. D. P. Whether misapplication of power (détournement de pouvoir) on the part of the agent should be considered as "illegality" there is a difference of opinion. Réglade (op. cit. 4I5) thinks it should be. Nézard (Le Contrôle Juridictionnel [1919] 3 REv. Gen. D'ADMIN. 400) holds the contrary opinion.

${ }^{15}$ On the whole subject of the exception dillégalité, see Réglade, op. cit.; Rives, L'Exception d'Illégalité (I908); I Garraud, Traité de Droit Pénal (2d ed. I913) $225 \mathrm{ff}$; Nézard, Le Contrôle Juridictionnel des Règlements d'Administration Publique (1909) 6 ff; Cahen, La Loi et le Reglement (1903) 369 ff; Moreau. Le Règlement Administratif (Ig02) 26r ; Hauriou, Précis de Droit Administratif et de Droit Public (Ioth ed. 1921) $67 \mathrm{ff}$; Duquesnel, Jurisprudence Comparée du Conseil d'Etat et de la Cour de Cassation (1912) $9 \mathrm{ff}, \mathrm{I37} \mathrm{ff}$; and Cartault, De l'Excès de Pouvoir à la Cour de Cassation (IgIr) 57 ff.
} 
tives" of the French administrative system which can not be ignored. Formerly, it offered a means of control over administrative conduct which was more frequently invoked than now, its importance having decreased in consequence of the remarkable extension of the control of the administrative courts, the effect of which has been to reduce correspondingly the control of the judicial courts. ${ }^{16}$ At best, however, it never was an effective means of control, first, because it necessitated a violation of the ordinance in order to bring the question of its legality before the courts, and second, because the power of the judge was limited merely to a refusal to impose the fine prescribed. He could not annul the ordinance which he declared illegal; it remained in effect and the administrative authorities might continue to enforce it against those who were unwilling to violate it and submit to prosecution.

\section{III}

\section{RECOURSE FOR EXCESS OF POWER}

It remained for the council of state to develop a form of recourse by which the administrative act could be attacked and declared null, by any person who had an interest in having the law respected by the administrative authorities, and this without the necessity of having to violate the ordinance and of submitting to prosecution. This remedy is known as recourse for excess of power (recours pour excès de pouvoir).$^{17}$ It is a distinctive creation of French administrative law $^{18}$ and its pièce essentielle. ${ }^{19}$ From the time of its creation in I80o the council of state

\footnotetext{
${ }^{10}$ Compare Réglade, op. cit. 420, $42 \mathrm{I}$.

${ }^{17}$ It thus happens that the administrative act is subject to a double control. It may be attacked simultaneously before the judicial courts and the administrative courts: before the former by means of the "exception of illegality"; before the latter by recourse for excess of power. The council of state may uphold the legality of the act while the judicial court may pronounce it illegal, the decision of the council of state having no binding effect on the judge. On the other hand, if the council of state annuls the act for excess of power its decision is binding on the judicial court. The latter cannot therefore treat the act as legal and impose fines for its violation. Not infrequently the judicial courts (which as stated above are more favorable to the administration than are the administrative courts) uphold the legality of administrative acts which the council of state pronounces null for excess of power. See Dalloz, I909, I, I62, for such a case involving the legality of the ordinance of a mayor relating to the ringing of church bells. For another similar case see Dalloz, I908, 3, 8I. See also Idoux, La Jurisprudence du Conseil d'Etat et de la Cour de Cassation Quant aux Points qui leur sont Communs (Ig08) I29 ff for a summary of the conflicting jurisprudence between the two supreme courts relative to the revocation by mayors of permits to public utility companies to use the streets. The former uniformly refused to annul such revocations whereas the latter generally pronounced them illegal. See also Duquesnel, op. cit. 69.

${ }^{18}$ Hauriou, op. cit. 422.

${ }^{10}$ Jèze, Principes Généraux de Droit Administratif (1914) 89. On the whole subject see du Clos, Le Recours pour Excès de Pouvoir (I906); Hauriou, op. cit. $420 \mathrm{ff} ; 2$. Laferrière, Traité de la Juridìtion Administrative (1887) 366-548;
} 
admitted recourse in annulment against ultra vires ordinances of prefects and mayors but throughout the period of the Restoration and the greater part of the July Monarchy it hesitated to allow recourse against ordinances issued by the Crown. ${ }^{20}$ It justified its refusal on the theory that the King was not an administrative agent but a political authority and that his acts could no more be subjected to judicial control than could those of Parliament. When in 1872 the council of state was reorganized, given much of the character of a judicial court and a position of greater independence as over against the Crown, express authority was conferred upon it to annul for excess of power the acts of the administrative authorities. Thus the theory of recourse for excess of power which had formerly rested entirely upon the jurisprudence of the council of state was now sanctioned by positive legislation of Parliament. This date marks a new starting point in the evolution of a remarkable body of case law dealing with remedies against ultra vires acts of the administrative authorities. Henceforth the council of state showed less timidity in admitting recourse against the acts of the Chief of State. It began at once to enlarge the category of authorities whose acts it was willing to annul, the category of acts which it permitted to be attacked, and the grounds upon which it allowed recourse.

Regarding the acts of the President of the Republic it still declined however to permit his so-called ordinances of public administration (les reglements d'administration publique) to be attacked on the ground of excess of power ${ }^{21}$ though other ordinances issued by him were attackable equally with those of inferior administrative agents. The view of the council of state was that this class of ordinances being issued by the President in pursuance of authority delegated to him by the Parliament they were a species of "dellegated legislation" assimilable to acts of Parliament and not therefore subject to judicial control.22 Moreover,

Duguit, Les Transformations du Droit Public (1913) ch. 6; also his Droit Constitutionnel (1889) (see index); Berthélemy, Traité de Droit Administratif (9th ed. 1920) 1042 ff; Jèze, op. cit. supra (see index); Dareste, Les Voies de Recourse Contre les Actes de la Puissance Publique (I914); Appleton, Les Progrès Récents du Recours pour Excès de Pouvoir (I9I7) ; Jacquelin, Les Principes Dominants dic Contentieux Administratif (I899) 227 ff.

${ }^{20}$ Jèze, op. cit. 2I7. Vivien at the time complained that the council of state would not allow recourse against acts of the Chief of State. Etudes Administratives (1859) $3 \mathrm{I3}$.

- These are ordinances issued by the President for supplementing or executing acts of parliament. They are issued in pursuance of authority conferred by Parliament and must be laid before the council of state for its advice-which advice, however, the President is not bound to take. As to the several types of Presidential ordinances see 2 Laferrière, op. cit. $9 \mathrm{ff}$; Berthélemy, op. cit. Ir2 ff; Moreau, Le Règlement Administratif (1902) 145 and 2 Duguit, Droit Constitutionnel (IgII) $45 \mathrm{Iff}$.

${ }^{22}$ Whether such ordinances are really the result of legislative delegation as the council of state claims, has been the subject of much discussion and of controversy among French jurists. The theory of the council of state was supported by most 
having been submitted to the council of state for its advice in advance of their promulgation it could not consistently admit recourse for the purpose of having them annulled. ${ }^{23}$ But as time passed the attitude of the council of state came to be more and more criticized as illogical and indefensible and before the close of the nineteenth century it began to show signs of a tendency to admit a breach in the ancient principle. Thus it asserted the right to determine whether such ordinances were regular in form, that is, whether they had been submitted in advance by the President to the deliberation of the council of state in general assembly for its advice. Then it went a step further and asserted the right to determine whether they were materially regular (au fond), that is, whether the ordinance was within the legal competence of the President, ${ }^{24}$ and finally, whether it was in accord with the general principle of the law for the execution of which it had been issued. In the meantime, also, the council of state had begun to allow recourse against individual acts in execution of ordinances of public administration..$^{25}$ This jurisprudence, which admitted specific acts against such ordinances to be attacked for excess of power but which denied recourse against the ordinances themselves, was criticized as wholly illogical ${ }^{26}$ and this the council of state finally recognized in a famous decision rendered in I907. ${ }^{27}$ Some years before, the President of the Republic had issued an ordinance of public administration in pursuance of authority delegated by an act of Parliament in I842, the effect of which, certain railroad companies contended, was to violate their contracts with the State and to deprive them of their rights under the law. They accordingly attacked the ordinance on the ground of excess of power, as being

of the early writers on French administrative law, such as Aucoc, Laferrière, DeCrocq, Batbie, St. Girons and others. The great majority of present day writers, however, reject the theory and hold that legislative power cannot be delegated. Such are the opinions of Esmein, De la Délégation du Pouvoir Législatif (I894) I Rev. PoL. ET PART. 209, and his Droit Constitutionnel (4th ed. 1906) 580 ff; Berthélemy, op. cit. 122; also his article; Le Pouvoir Règlementaire ds Président (1898) I5 Rev. Pol. ET PARL. 5, 322; Jèze, op. cit. 222; also his note in $25 \mathrm{R}$. D. P. 45 ; Nézard, op. cit. 33; Hauriou, op. cit. I50; Appleton, op. cit. I0, and Duquesnel, op. cit. I4I. Among contemporary writers who defend the theory of legislative delegation may be mentioned Moreau, Le Reglement Administratif (I902) I80; Cahen, La Loi et le Règlement (1903) 232 ff; and Teissier, Responsabilité de la Puissance Publique (I906) Ig.

${ }^{2}$ It may be remarked in this connection, however, that it is to the council $o_{2}$ state in general assembly that ordinances are submitted for its advice and not to that part of the council which exercises contentious jurisdiction. The body which hears actions for annulment on account of excess of power is not therefore the same body which gives its advice to the President.

${ }^{24}$ Jèze, 23 R. D. P. 72 and 25 ibid. 42 ff.

${ }^{25}$ Duquesnel, op. cit. 138.

${ }^{\infty}$ Compare Nézard, op. cit. 2I and the opinions there cited and Duquesnel, op. cit. 139 and the opinions cited by him.

${ }^{27}$ Compagnies du Nord, d'Orleans, du Midi, de l'Est et de l'Ouest, December 6, I907. 
beyond the legal competence of the President. The minister of public works appeared for the government and argued that it was a long established principle of French jurisprudence that ordinances of public administration issued by the President could not be made the object of recourse for excess of power. The council of state, however, abandoned the century-old rule, took jurisdiction of the case and annulled the presidential ordinance. It declined, however, to abandon the theory of legislative delegation upon which it had always based its refusal to admit recourse against such ordinances. To this theory it still clings, though it no longer considers it as a sufficient reason for treating presidential ordinances as immune from attack and annulment when they are ultra vires. 28

The decision was a landmark in a long and remarkable evolution of the jurisprudence of the council of state and it has been frequently affirmed since 1907.20 It afforded a striking illustration of the independence of the council of state as over against the government and is a sufficient answer to the assertion of critics that its decisions are usually in conformity with the wishes of the government. In this case the government was deeply interested in obtaining a decision upholding the validity of the ordinance and it made every effort to induce the council of state to stand by its former decisions and refuse the recourse demanded, but without success.

The full effect of the decision can only be appreciated when we remember that it is the practice of the French Parliament-one which has been greatly extended in recent years-to formulate its acts in very general terms and to delegate to the President the power of issuing ordinances not only to regulate the details of their execution but often to supplement in important respects their provisions. ${ }^{30}$ These ordinances though not in form statutes are yet intrinsically a species of supple-

${ }^{23}$ The probable reason why the Council of State refuses to abandon the theory of delegated legislation is that if it were not maintained it would be difficult to defend the constitutionality of the action of Parliament in charging the President with issuing ordinances of a legislative character. Jèze (25 R. D. P. 45) criticizes the refusal of the council of state to abandon its theory of legislative delegation. When the President is charged with issuing ordinances there is, he says, no "delegation" of the power of legislation, but simply an "invitation" to regulate certain subsidiary matters which could not well be dealt with in the statute. The decision on the merits of the issue was therefore right, he says, but it was wrong in so far as it was based on the theory of delegated legislation. To the same effect see 2 Duguit, Droit Constitutionnel (I9Ir) 464, who points out that the reasoning of the council of state was contradictory because if there was legislative delegation the President would no longer be an administrative authority and hence recourse against his ordinances would not be allowable.

2 See the cases cited by Jèze, Principes Généraux, 22, note 2 . The importance of the case is discussed by Jèze in 25 R. D. P. 5 I ff; by Nézard, op. cit. 22 ff, and by Duquesnel, $o p$. cit. I $42 \mathrm{ff}$.

* See the examples mentioned by 2 Duguit, Droit Constitutionnel (I9II) sec. I6r, and by Nézard, op. cit. 23 ff. 
mentary executive legislation which frequently impose obligations on the citizens and affect their rights of person and property. ${ }^{31}$ In consequence of the decision of 1907 the legality of all such ordinances is subject to review by the council of state and when they are found to be ultra vires they are annulled with the same freedom with which the acts of inferior administrative authorities are annulled. The effect has been to enlarge immensely the domain of judicial protection against the arbitrary and illegal acts of the government.

\section{IV}

THE DOCTRINE OF ACTES DE GOUVERNEMENT

There still remain, however, two categories of presidential acts against which the council of state refuses to admit recourse for excess of power. The first of these are the decrees or decree-laws, as they are sometimes called, issued by the President in pursuance of authority conferred by the Senatus-Consultum of 1854 for the regulation of affairs in the colonies. ${ }^{32}$ Now the power of the council of state to annul is expressly restricted by the law of 1872 to acts of the "administrative authorities" and it has been the view of the council of state all along that when the President issues a colonial decree he acts not as an "administrative" but as a "political" authority. ${ }^{33}$ Such decrees therefore are not attackable for excess of power. But it may now be said that whatever force this distinction may have formerly had, it has had little or none since rgo7 when the council of state abandoned the distinction between simple ordinances and ordinances of public administration and extended the doctrine of recourse for excess of power to the latter. Logic and consistency therefore would require the council of state to abandon the distinction between the President as an administrative agent and the President as a political authority and admit recourse for excess of power against the acts performed by him in both capacities without distinction. $^{34}$

The second category of presidential acts against which the council of state refuses to admit recourse for excess of power are the so-called "acts of government" (actes de gouvernement). The distinction between acts of this character and other acts of the President has long been an established principle of the jurisprudence of the council of state and it too rests, in the main, on the distinction which the French make between the President as an administrative agent and as a political authority-between the function of "administering" and the function

\footnotetext{
${ }^{11}$ Compare I Duguit, op. cit. supra note 30 , at p. 195.

This Senatus-Consultum has lost its constitutional character but still retains its force as a statute.

"Compare Tessier, op. cit. I8.

"Compare Jèze, Principes Généraux, 216; Nézard, op. cit. 58; Tessier, op. cit. s8; and Duquesnel, op. cit. I44.
} 
of "governing." The conception of "actes de gouvernement" has played an important rôle in French administrative law and it has been the subject of much controversy among French jurists and text writers. $^{35}$ The difference of opinion has related not so much to the general principle as to where the line of demarcation between such acts and simple administrative acts should be drawn. ${ }^{36}$ Some of the older writers construed the category of government acts so broadly as to bring within its scope nearly every measure which in the judgment of the government was a public necessity or which even subserved an important public interest. ${ }^{37}$ Such acts might violate private rights but it was the theory that if they were necessary to the social or national defense the government might resort to them, in which case it was responsible only to Parliament and not to the council of state. There is still no agreement as to what acts fall legitimately within this category although the tendency of opinion and of the jurisprudence has been to reduce the number to very narrow limits. The jurisprudence of the council of state and the tribunal of conflicts has undergone a remarkable change in regard to such acts. During the Second Empire they interpreted the doctrine very broadly and refused to allow recourse against a great variety of acts such as the suppression of newspapers, decrees forbidding the distillation of grains, the confiscation of the lands of the children of Louis Philippe, the seizure of certain

${ }^{25}$ See 4 Dufour, Droit Administratif (1870) $600 \mathrm{ff} ; 2$ DuCrocq, Droit Administratif (7th ed. 1897) $20 \mathrm{ff} ; 7$ Batbie, Droit Administratif (2d ed. 1885) secs. 389 ff ; 2 Laferrière, $o p$. cit. ch. 2; I Aucoc, Conférences sur le Droit Administratif (1882) sec. 289; Jacquelin, op. cit. 297 ff; Berthélemy, op. cit. II5 ff; Jèze, op. cit. supra note 34, at pp. $229 \mathrm{ff}$; Hauriou, op. cit. $43 \mathrm{I}$ ff ; Duguit, Transformations, I94 ff; Baumgart, Les Garanties Juridictionnelles du Droit Public Moderne (1914) $127 \mathrm{ff}$; Courtois, Théorie des Actes de Gouvernement (1899), where a full bibliography may be found; Tessier, op. cit. 4I ff and 124 ff; Brémond, Des Actes de Gouvernement ( 1888 ) 5 R. D. P. 23 ff; and Michoud, Des Actes de Gouvernement in I Annales de l'Enseignment Supérientr de Grenoble (I889) 263 ff.

${ }^{26}$ Many distinguished French jurists, however, condemn the theory in toto as being arbitrary and contrary to the spirit of modern French law. There are not, or should not be, they maintain, any "acts of government." Such is the view of Berthélemy, op. cit. 121; Jèze, op. cit. 232; Brémond, art. cited at p. 23; and Michoud, art. cited at p. 82. Certain writers who believe the theory is useful and should be retained would avoid the full consequences by allowing the courts to refuse to apply such acts when they are illegal, without allowing them to be annulled. Others would allow individual measures in execution of such acts, but not the acts themselves, to be attacked, and as regards measures in execution of a state of siege, the council of state has adopted this solution. But as Brémond (art. cited at p. 64) pertinently asks, of what advantage is it to the government to have its decrees exempted from judicial attack if the specific acts of its agents in execution of them may be attacked and annulled?

${ }^{a}$ Among such acts were measures of protection against riots, insurrection, floods, epidemics and even measures of sanitary police. The suppression of certain newspapers and measures against the members of dethroned dynasties were also included in this category. 
manuscripts of the Duc d'Aumale, etc. ${ }^{38}$. But after 1872 when the reorganized council of state acquired a larger degree of independence, it adopted a different attitude and did not hesitate to allow recourse against many so-called actes de gouvernement which were no different in principle from those with which the old council of state had declined to interfere. ${ }^{39}$ By a series of decisions it has steadily reduced the hitherto large domain of governmental acts which escaped the control of the council of state until today it includes little more than such acts of the President as the calling of elections; summoning, adjourning and closing of parliament; the conduct of foreign relations $;^{40}$ measures in connection with the maintenance of a state of siege and certain extraordinary measures in time of war in the interest of the national defense."1 Of these the last three alone are of any importance. As the jurisprudence now stands the theory of acts of government presents little danger to the citizens for there are few administrative acts left the legality of which is not open to attack before the council of state. ${ }^{42}$ The acts of the President, once regarded as those of a representative of the national sovereignty, have gradually ceased to be such and are now treated, with a very few exceptions, as those simply of an administrative agent. This long-hoped for situation is due to the impartiality and independence of France's two great administrative courts, the council of state and the tribunal of conflicts. ${ }^{43}$

\footnotetext{
${ }^{3}$ Some of these cases are discussed in my article, Judicial Control of Administrative and Legislative Acts in France (Ig15) 9 AMrer. Pol. Scr. Rev. 656. See also Brémond, art. cited note 35 , at pp. 63, 64; 2 Laferrière, op. cit. 37-38; Hauriou, op. cit. 434 and Duguit, The French Administrative Courts (19I4) 29 PoL. ScI. QUART. 385, 395.

${ }^{3}$ See Jèze, (Ig03) 3 Rev. Gen. D'ADMIn. 392 ff; 2 Laferrière, op. cit. 39; Michoud, art. cited note 35, at pp. 16-17; and Duguit, art. cited note 38 , at p. 396 and his Transformations, 199.

${ }^{\text {to }}$ There are even indications of a disposition to admit recourse against illegal acts of diplomatic and consular representatives. Thus the council of state has recently held that it was competent to award damages against a minister for refusing to marry two French citizens. Jèze criticizes the refusal of the council of state to allow recourse against the acts of diplomatic agents and predicts that in the near future its attitude will be abandoned. He thinks also that the acts of the administration in execution of treaties and conventions will likewise be brought under the control of the council of state. 2x R. D. P. $78 \mathrm{ff}$.

12 During the World War the council of state refused to allow recourse against decrees of the President inspired by raison d'Etat. Réglade, L'Exception d'Illegelité (I923) 40 R. D. P. 405.

- Compare Jèze, op. cit. supra note 34 , at p. 234 and Réglade, art. cited at p. 405, who remarks that the theory of acts of government as formerly maintained has been completely abandoned by the council of state and the tribunal of conflicts.

${ }^{43}$ Duguit, Transformations, 194, 200.
} 
GROUNDS OF ANNULMENT OF ADMINISTRATIVE ACTS

The council of state and the tribunal of conflicts have by their decisions not only extended the list of administrative agents whose acts may be annulled for excess of power and enlarged the category of such acts, but they have also greatly extended the grounds upon which they may be annulled. Originally these grounds were: incompetence, irregularity (vice de forme) and violation of the letter of the law. For a long time both tribunals proceeded on the theory that administrative acts were, in the main, discretionary in character and so long as they were within the technical competence of the authority performing them they were not permitted to be attacked for excess of power, even though they were contrary to the spirit of the law and were done for another purpose than that contemplated by the law. The council of state always refused to inquire into the motive which inspired the agent or the real object sought to be accomplished by the act. After 1872, however, it began to take a different view and in time there was developed the doctrine of "misapplication of power" (détournement de pouvoir) according to which it will annul an administrative act which, though within the legal competence of the agent, is in reality done for another purpose than that which the law authorizing it had in mind. Thus a municipal council is dissolved by a prefect ostensibly because of irregularities in the election but in reality because it is politically opposed to the prefect; a minister of war excludes a grain dealer from bidding for a government contract because his political opinions are opposed to those of the government; a mayor revokes a permit, refuses permission to a hackman to park his carriage at the railway station, forbids the ringing of church bells during certain hours, orders the closing of certain establishments-in all these cases for other reasons than those intended by the law. ${ }^{44}$ It is still a rule of the council of state, however, that it will not presume that an administrative agent intends to use his power for another purpose than that authorized by the law ${ }^{45}$ and as late as 1903 it denied that it was within its competence to inquire into the motives which animated officials in exercising their powers. But in I9I4 it appears to have definitely

"For these and other cases among many see Hauriou, op. cit. 457-8; 2 Laferrière, $o p$. cit. 453 ff; Jèze, 23 R. D. P. 265 ff, and 25 ibid. 682; Duguit, L'Acte administratif et L'Acte Juridictionnel (I906) 23 R. D. P. 413-47I. Even the refusal of a minister to appoint a candidate to office who is entitled to the appointment, where the real motive is to abolish the office, and the exclusion of a candidate from an examination when the actual reason is foreign to the interest of the public service, have been held to be détournement de pouvoir. The council of state even annuls the refusal of municipal councils to appropriate the sums of money which are obligatory upon them in execution of certain laws enacted by Parliament. Their persistent refusal to make such appropriation has led to numerous conflicts between the government and the municipalities. See Baumgart, op. cit. 123.

${ }^{4}$ Jèze, 40 R. D. P. 521. 
abandoned this view and in a case involving the validity of a municipal ordinance for the "pretended" reorganization of a certain municipality it annulled the ordinance on the ground that the reason alleged was false, the real motive being to get rid of certain municipal employés because of their political hostility. ${ }^{46}$

The result of this extension of the doctrine of misapplication of power has been to reduce very greatly the discretion of the administrative authorities and to bring under the control of the council of state a large realm of administrative action which formerly escaped its watchful eye. Formerly mayors and prefects under the pretext of protecting the public health or safety frequently issued ordinances the real purpose of which was the financial interest of the local government, some railroad company or even the political interests of the government. Today their real motives in all such cases are subjected to the searching scrutiny of the council of state.

\section{VI}

PERSONS QUALIFIED TO ATTACK THE LEGALITY OF ADMINISTRATIVE ACTS

No less interesting has been the development of a new jurisprudence by which the doors of the council of state have been opened wider and wider to private individuals who may wish to attack the acts of the administrative authorities. For a long time no one who was unable to show that the act complained of violated a legal right of his was permitted to knock at its doors. Later the council of state began to admit the existence of mere interest on the part of the plaintiff as a sufficient ground of attack. But in the beginning it insisted that this interest must be direct and personal, pecuniary or material; mere impersonal interest such as any good citizen might have in the observance of the law was not sufficient. Gradually, however, the council of state began to admit one relaxation after another from the rigor of the early rule until today the plaintiff is merely required to show that he has a simple interest in the annulment of the act-an interest which may be only moral rather than material and which may not be detachable from the common interests of all citizens or from those of an association of which he may be a member. ${ }^{47}$ Thus any member of an association of functionaries has sufficient interest to attack an appointment, a promotion or a dismissal made in violation of ministerial civil service regulations. ${ }^{48}$ So has any

\footnotetext{
"Appleton, Les Progrès Récents du Recours pour Excès du Pouvoir (Ig17) 37. See other cases cited by Baumgart, op. cit. I2I where the council of state considered the motives of administrative authorities in order to determine whether they were guilty of détonrnement de pouvoir. Compare also Duguit, Transformations, $207 \mathrm{ff}$.

"But it is not to satisfy the interest of the plaintiff that recourse is allowed. His interest is only the justification. The real interest is to assure observance of the law. Berthélemy, op. cit. I045.

${ }^{4}$ It may be remarked in this connection that the council of state does not hesitate to annul the acts of ministers, prefects and mayors done in violation of their own ordinances. They are free at any time to abrogate or modify their ordinances,
} 
member of a university faculty who wishes to attack the legality of a decision made by the faculty for the awarding of a prize, contrary to its own regulations. Similarly, the council of state has held that an innkeeper whose house fronts on a public square has sufficient interest to attack the order of a mayor forbidding the holding of a market on the square, although the order violates no legal right of his. Recently the council of state has gone to the length of annulling appropriations made by municipal councils when they are not within its legal competence ${ }^{40}$ as well as ordinances relating to the management or disposal of the municipal patrimony or which involve the imposition of financial charges upon the municipality, when they are not authorized by law. Likewise any voter has sufficient interest to attack and have annulled a municipal ordinance dividing an election district in violation of the law. ${ }^{80}$

As a result of these "new conquests" the doors of the council of state today are open to nearly every citizen who may wish to attack as ultra vires any act of an administrative authority from the President down to the mayor, including also the acts of municipal councils. ${ }^{51}$

\section{VII}

THE DOCTRINE OF PARALLEL RECOURSE AND THE COUNCIL OF STATE AS JUDGES OF FACTS

Recourse to the council of state for the purpose of annulment on the ground of excess of power has, however, always been regarded as an extraordinary remedy and it is not open to the individual whenever there is a parallel remedy by pursuing which he can obtain satisfaction.

but so long as they remain in force the council of state insists that they shall be respected. It thus happens that while Parliament has refused to pass a civil service law for the protection of functionaries the council of state has come to their resctue and protects them against the arbitrary conduct of their superiors. See the cases cited by Jèze, 23 R. D. P. $483 \mathrm{ff}$. The council of state will equally annul the verbal act of a mayor dismissing a municipal employé in violation of the regulations.

* The council of state reached this important conclusion only in $190 \mathrm{I}$ in the now famous Casanova case where it affirmed that any taxpayer had sufficient interest to enable him to attack an unauthorized appropriation of a municipal council. The decision was reaffirmed in the Petit case in 1905, in the case of Camut and others in 1906 and in the case of Pressensé et Morhardt in Igr. For a long time the council of state had refused to permit taxpayers generally to attack the ordinances of municipal councils on the ground of excess of power. See the cases cited by Appleton, op. cit. 19. For a long time also it refused to allow recourse against administrative acts which were in the form of contracts. But recently it has abandoned this view. See the cases cited by Jèze in 23 R. D. P. 264 .

${ }^{\infty}$ As to these and other cases see Baumgart, op. cit. $65 \mathrm{ff}$.

ss As to the development of this jurisprudence see especially Jèze, Principes Géneraux (index); also his article in 23 R. D. P. 254 ff; Hauriou, op. cit. $437 \mathrm{ff}$; Duguit, Transformations, ch. 6; Appleton, brochure cited note 46, at pp. I8 ff; Baumgart, op. cit. $64 \mathrm{ff}$; Baudouin, Notion de L'Intérêt dans le Recours pour Excès de Pouvoir (.1904) and Le Fur, (I9II) I REv. Gen. D'Admin. I2 ff, I29 ff. 
This is the theory of "parallel recourse" which was developed by the council of state mainly for the purpose of safeguarding against encroachment the jurisdiction of the judicial courts as well as that of the other administrative courts, ${ }^{52}$ for it is well to remember that the council of state is not the only tribunal which may annul an administrative act, nor is it the only one which may pass on the question of the legality of such acts. It is out of respect for the jurisdiction of these other courts that the council of state insists that whenever the individual can obtain relief by recourse to them he must knock at their doors rather than at its. Furthermore, if he may obtain satisfaction from the council of state by another proceeding than recourse in annulment for excess of power he must follow that procedure. In this, as in other respects, however, the council of state has shown in recent years a disposition to admit relaxations from the rigor of the old rule, so that the doctrine of parallel recourse has been greatly undermined if it has not been abandoned..$^{53}$

Suitors have found, however, that the remedy of recourse in annulment before the council of state for excess of power is usually more effective than the so-called parallel remedies and whenever it is open to them it is pursued. No other form of action offers the same advantage..$^{\text {s4 }}$ The remedy of exception d'sllégalite before the judicial courts, for example, necessitates a violation of the administrative act in order to attack its legality and if the court finds it to be illegal it cannot annul the act. Likewise a taxpayer from whom an unauthorized tax has been collected is still exposed to the liability of being obliged to pay another tax so long as the act under which it is collected has not been annulled. And the same situation results from the holding of an election in accordance with an apportionment made contrary to the law. In these and like cases the only effective remedy is the annulment of the illegal act and this only the council of state can do, and it can do so only by the procedure of recourse for excess of power. The council of state, always anxious to protect the people against arbitrary and illegal conduct, could not have failed to be affected by these considerations, and having already extended the notion of interest so as to enable almost any citizen to invoke its protection, it could no longer close its doors to those who could obtain only an ineffective remedy by means of a parallel recourse either to it or another tribunal. It accordingly broke with the old jurisprudence and now admits recourse for excess of

ss As to parallel recourse see 2 Laferrière, op. cit. 444 ff; Baumgart, op. cit $77 \mathrm{ff}$; Hauriou, op. cit. $444 \mathrm{ff}$; Marie, L'Avenir du Recours pour Excès du Pouvoir (1899) I6 R. D. P. 274 ff; and Gavan, La Théorie du Recours Parallele Devant le Conseil d'Etat (rgI4).

${ }^{53}$ Compare Baumgart, op. cit. 78 and Appleton, brochure cited note 46, at pp. 24-28 who goes to the length of saying that such is the jurisprudence of the council of state to-day that one may regard as abrogated the rule that recourse for excess of power is not allowable when there exists a parallel recourse.

st Gavan, op. cit. 18. 
power in many cases where it was formerly refused..$^{55}$ As has already been remarked, the civil judges show much more hesitation if not timidity in declaring administrative acts illegal than does the council of state. In many cases the council of state has annulled acts which the civil courts have sustained as legal..$^{\text {s6 }}$

For a long time the council of state insisted that in actions for annulment on the ground of excess of power it was a judge merely of the law and not of the facts, and that it could not therefore inquire into the expediency or utility of an administrative act. Theoretically the council still holds this view, but in fact it is not strictly followed, if indeed it is possible to do so. Thus where the administrative agent is required, as he sometimes is, to motiver an ordinance which he issues, the council of state does not hesitate to determine whether the reasons given are in accordance with the facts. ${ }^{57}$ There are also many recent decisions in which the council of state has certainly been influenced by what it regarded as the inexpediency ('inopportunité) of the act attacked. This has been notably true in cases of municipal appropriations alleged to be ultra vires, of ordinances of mayors relative to the police des cultes (ringing of church bells, religious ceremonies, processions, etc.), of measures relative to public health and sanitation. derogations by employers from the weekly rest law, etc. ${ }^{.8}$

\section{VIII}

EFFECTS OF ANNULMENT OF ADMINISTRATIVE ACTS

The competence of the council of state in a proceeding for annulment on account of excess of power is limited to pronouncing the nullity of the act. It cannot reform or modify it or substitute a new one in its place. But unlike the decisions of a judicial court in the proceeding known as exception d'illégalité the effect operates erga omnes; that is, not only the plaintiff but all other persons may benefit from the decision. All acts which have been done in consequence of the nullified ordinance are illegal and the injured plaintiff is entitled to reparation. ${ }^{59}$ But the decision which pronounces the annulment

${ }^{\text {ss }}$ Compare Appleton, op. cit. 24-29.

Gavan, op. cit. I8.

${ }^{37}$ On the whole matter of the council of state as judges of facts see the notes by Jèze, in 24 R. D. P. $54 ; 28$ ibid. $286 \mathrm{ff} ; 39$ ibid. 390 ff and 40 ibid. $43 \mathrm{ff}$. It goes even farther, says Jèze, and decides whether the agent has drawn from the facts the legal consequences which follow. See also the recent cases cited by Chalvon-Demersay, De l'Examen du Fait par le Conseil d'Etat statuant en Matière de Recours pour Excès de Pouvoir (1922); also Baumgart, op. cit. 9I, and the cases there cited.

See the review by Baumgart, op. cit. 92-II4.

"It may be remarked, however, that there are no means by which the administrative authorities may be compelled to give effect to a decision of the council of state. Thus it may annul the decision of a prefect refusing to accord to an employe the weekly day of rest to which he is entitled under the law, but it cannot 
cannot at the same time award the damages to which he is entitled. If the injury was the result of the personal fault of the agent, a damage suit may be brought against him in a judicial court; if the State is responsible (that is, if the injury results from a fault of service) it is necessary to bring another and a different action against it before the council of state. This latter action is known as the recours ordinaire contentieux, sometimes as the recours contentieux de la pleine juridiction. Its purpose may be not only the recovery of damages but the reduction of a tax, reimbursement of expenses, payment of a pension, restitution of property, etc. Unlike a proceeding for annulment it asks that something positive be done for the plaintiff and unlike it also, it is directed not against the act but against the personne administrative (the State, the department, or the commune). In order to bring it the plaintiff must show that a right has been violated; the mere existence of an interest is not sufficient.

Some French jurists criticize the distinction which is made between the two forms of action and maintain that the council of state should at the time it pronounces the annulment of the act, award damages to the plaintiff if he is entitled to reparation. ${ }^{60}$ This would not only economize the time of the council of state but it would relieve the plaintiff of the necessity of an additional action. In fact it is not always clear which of the two recourses should be pursued. Thus the minister of war refuses to bestow a medal to which a war veteran is entitled. Is the remedy a proceeding for the annulment of the ministerial decision or the ordinary contentious recourse to secure the medal? If the former remedy is pursued and the decision annulled would the effect be to give the claimant his medal ?a1 Formerly the council of state refused to allow recourse for annulment when the effect of annulment would be to condemn the administration to pay damages or make restitution; it insisted that the proper remedy in such cases was the ordinary contentious recourse. ${ }^{62}$ In proceedings for annulment it refuses to do more than annul, and it hesitates to do even that when the effect would be to accomplish an object for which the ordinary contentious jurisdiction

compel him to obey the decision. Likewise it may annul his refusal to insert in the departmental budget an obligatory appropriation, but it has no means of forcing him to do it. In a number of cases it has annulled the dismissal by mayors of municipal employés, but by means of monthly suspensions, which the law allows, mayors have avoided the effect of the decisions. See Duguit, Transformations, 218-219. Similarly, the council of state may condemn the administration to pay damages to an individual but it has no means of compelling it to conform to the decision. See Baumgart, op. cit. I43.

" Compare Jèze, Principes Généraux, 96.

"Such was the case of Uston de Villeréglan (22 R. D. P. 105). The council of state annulled the decision of the minister but held that the annulment did not give the claimant a right to the medal.

"See for the cases of Théveneau (rgoj) and Desplogues (19II), note by Jèze, 29 R. D. P. 266. 
was intended. ${ }^{63}$ But lately it has shown a disposition to admit a relaxation from the rigor of the old rule. Thus in IgII it allowed certain functionaries who had been dismissed from their offices to join their demands for the annulment of the acts of dismissal with their demands for damages, thus consolidating the two actions. ${ }^{64}$ Again in the following year (Lafage case) it allowed an action for annulment against the decision of a minister refusing to a military surgeon an indemnity for representation to which he was entitled under a presidential decree and it annulled the decision although the effect was to give the surgeon his indemnity. ${ }^{65}$ The case was exactly the same as those of Thévenean and Desplogues in 1907 and I9II respectively, where the council of state had refused to allow an action for annulment because the effect of annulment would have been to condemn the administration to pay damages.

These relaxations from the former practice have created the belief among certain jurists that ultimately the council of state will abandon the old rule and that the distinction between the two proceedings will tend to disappear. ${ }^{86}$ Professor Hauriou concludes from the recent decisions that the new jurisprudence will doubtless become general and that the recourse for annulment for excess of power will tend more and more to become absorbed by that of the ordinary contentious recourse and that out of the consolidation will develop an action for indemnity, an incident of which will be a demand for the annulment of the act causing the injury. In any case the importance of the proceeding of ordinary contentious recourse seems certain to increase while that for annulment will decline, although it will probably never entirely disappear. ${ }^{6 \tau}$ French jurists are not lacking who condemn the distinction

* Thus it annulled the dismissal of a functionary but told him that the recovery of his arrears of salary could only be obtained by means of a separate action, the ordinary contentious recourse. In another case it annulled the order of a prefect authorizing the erection of a dangerous building but refused in the same proceeding to order the destruction of the building. In still another case it annulled the decision of a mayor establishing a property line but refused to condemn the commure to reimburse him for the expense he had incurred in constructing a building which had to be removed. In all these cases the remedy of the plaintiff lay in an additional action, the ordinary contentious recourse.

"Cases of Blanc, Argaing, and Bézie, Sirey, 1912, III, 130. See also Baumgart, $o p$. cit. 43 , note $\mathrm{I}$.

${ }^{\infty}$ Jèze, note in 29 R. D. P. 266.

"Such is the opinion of Professor Jèze, 29 R. D. P. 266. He criticizes Laferrière for the reasons which he gives for maintaining the distinction between the two proceedings and argues that the law of $I 872$ which fixes the jurisdiction of the council of state never meant to say that it could only annul in the proceedings for excess of power. P. 284. But Professor Moreau, defending the jurisprudence of the council of state, remarks that if it can only annul in such a proceeding it is because it is only asked to do this. As Jèze points out, however, (ibid. 290) suitors in fact often ask it to do more. Compare also the remarks of I Duguit, Droit Constitutionnel, 280.

"Précis de Droit Administratif (ed. I921) 418. 
which the council of state maintains between recourse in annulment for excess of power and the ordinary contentious recourse and who maintain that they should be consolidated, or that the latter should include the former so that two separate actions would not be necessary to enable the plaintiff to recover damages or obtain restitution of what properly belongs to him. ${ }^{68}$

\section{IX}

RESPONSIBILITY OF THE STATE FOR ACTS OF ITS AGENTS

Guarantee of reparation for loss or damage which the individual may have sustained on account of the torts of the state or its agents is one of the features of French administrative law which distinguishes it fundamentally from American and English law. In England and the United States it is a general principle of law that the State is not liable to private individuals for damages caused by the tortious acts of its agents. ${ }^{69}$ In general the remedy of the individual in such cases is an action for damages in a judicial court against the officer or agent committing the wrong, for in these countries the principle that the agent is personally liable and may be sued, is the general rule. ${ }^{70}$ Originally

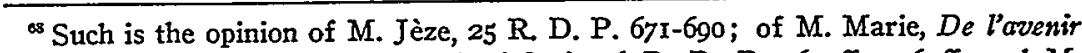
du Recours pour Excès de pouvoir (I899) I6 R. D. P. $265 \mathrm{ff}, 476 \mathrm{ff}$, and $\mathrm{M}$. Baumgart, op. cit. $4 \mathrm{I}$ ff.

${ }^{\infty}$ Compare Moore, Liability for Acts of Public Servants (1907) 23 L. Quart. Rev. I2 ff; Maguire, State Liability for Tort (1916) 30 Harv. L. Rev. $20 \mathrm{ff}$; Dicey, Law of Constitution (2d ed. I880) I80 ff; Parker, State and Official Liability (Igo6) I9 HARv. L. REv. 335 ff ; Duguit, Transformations, I77 ; Goodnow, Principles of the Administrative Law of the United States (I903) $387 \mathrm{ff} ; 2$ Lowell, Government of England (1908) 493; Nesmes-Des Marets, De la Responsabilité Civile des Functionnaires (1910) $24 \mathrm{ft}$ and Couzinet, La Responsabilité des Groupements Administratifs (I9II) $150 \mathrm{ff}$ and the English authorities cited by him. The case of Bainbridge v. The Postmaster Gevteral [1906] I K. B. 178, where the King's Bench division held that an individual who was injured by the State owned and operated telegraph system could not recover damages from the State or the telegraph administration, illustrates the English rule. The Crown, said the court, was not liable for the torts of its agents; the remedy of the individual, so far as there was any, was a personal damage suit against the agent who committed the injury. The same general principle prevails in the United States, though it may be remarked that the establishment of courts of claims, the enactment of workingmen's compensation laws, and the passage of special acts allowing the State to be sued in certain cases, indicate a tendency to abandon, in part at least, the old rule of non-liability of the State for the misdoings of its agents.

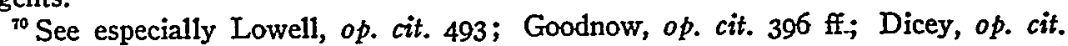
I80 ff; Ashley, Local and Central Government, 300; and 2 Anson, Law and Cinstom of the Constitution (1897) 477. There are, of course, exceptions to the general rule stated above. Thus in England the individual agent is not personally liable on contracts made by him for public services, even when the contracts are not authorized (Dumn v. Macdonald [1893] I Q. B. 40I, 555); nor is he liable for tort in an action brought against him in his official capacity. (Raleigh $v$. Goschen [I898] I Ch. 73) See also the cases cited by Lowell, op. cit. 493, notes 3 and 4. 
the doctrine of the non-liability of the State was the rule in France but it has long since been abandoned, at least so far as its responsibility for the acts of administrative agents is concerned. ${ }^{71}$ The new principle of State responsibility was the result, in part, of the growth of the democratic conception that the State is a moral person possessing duties as well as rights; and, in part, of the enormous expansion of the activities of the State by which it came to be the largest employer of labor. As such it ought to assume the same responsibility for indemnifying those who sustain injuries on account of its faults or negligence as it compels private employers of labor to do. ${ }^{72}$ In response to this change of sentiment there has been developed in France an elaborate body of jurisprudence, mainly the work of the council of state and the tribunal of conflicts, which definitely fixes the responsibility of the State and which assures to the injured individual reparation, such as is entirely unknown in Anglo-Saxon countries. ${ }^{73}$ The basic principle of this jurisprudence is that the State is liable to the individual not only in contract but also in tort where the tortious act of the agent is not a purely personal act; that is, the state is liable where the injury is due to a fault of service (faute de service). The fault may be due to an error, an omission, an act of negligence or even of want of judgment on the part of the agent. On the other hand, if the injury is done by the agent in his personal and unofficial capacity, that is, if it results from a fait personnel, he and not the State is liable. ${ }^{74}$

\footnotetext{
"In general the State is not responsible for the acts of judicial magistrates. See Duguit, Transformations, 247-270 and Couzinet, op. cit. 76-83. But by an extraordinary proceeding known as prise à partie, an action in damages may be brought by the injured party against a judge or even the entire court for such acts as fraud, extortion, arbitrary conduct, wilful denial of justice, etc. See MorizotThibault, $D e$ la Responsabilité des Magistrats, II-I2, and my article on The French Judiciary (I9I7) 26 YALE LAw JourNal, 349, 374. By a law of I895 the French Parliament made provision for a system of State reparation for persons wrongfully convicted of crimes. See my article, on Criminal Procedure in France (1916) YALE LAw Journal, 256, 282-283, and the cases there cited. Regarding damages resulting from legislative acts the general rule is the irresponsibility of the State but the tendency of the council of state is to admit more and more the responsibility of the State for damages resulting from legislative acts which violate contractual rights. See Couzinet, op. cit. especially pp. 68 and 74 and Duguit, Transformations, 242-243.

7 Compare Walton, The French Administrative Courts and the Modern French Law as to the Responsibility of the State for the Faults of its Officials (1918) I3 InL. L. REv. 205-207. "The principle is," says M. Hauriou (op. cit. 363), "that the administrative enterprise must be managed subject to the rights of third parties." As to the evolution of the idea of State responsibility see Couzinet, op. cit. ch. I.

"Curiously enough there is no allusion in the Declaration of Rights, in any of the constitutions or in any of the laws of France, to the responsibility of the State, although there are numerous references to the responsibility of functionaries. Compare Duguit, Transformations, 222-225.

7t This is the general principle, to which there are some exceptions. See Jèze, Principes Gétuéraux, I02.
} 
In the former case the remedy is a suit (le recours contentieux ordinaire) against the administration before the council of state; in the latter case it is a personal damage suit in a judicial court against the agent.

But prior to 1870 an administrative agent could not be sued without the consent of the council of state-a consent which was rarely given. ${ }^{75}$ In the latter year the law was changed so as to permit such suits without the consent of the council of state. The administration is always free, however, to oppose the suit by "raising the conflict" if it thinks the act complained of is not the personal act of the functionary, in which case, it is for the tribunal of conflicts to decide the issue. ${ }^{76}$ If it decides that the act was a fait de service rather than a fait persomel the judicial court is divested of jurisdiction and the suit must be discontinued. ${ }^{7 r}$ In that event the remedy of the individual is a suit against the State before the council of state. The competence of the council of state to hear actions against the State for damages on account of the faults of service of its agents was definitely affirmed by the tribunal of conflicts in the famous Blanco case in 1872 which involved the liability of the State for damages sustained by a child in the government tobacco factory at Bordeaux. This decision opened the flood gates and from then until now a steady stream of damage suits has poured in upon the council of state.

Not long thereafter the question was presented as to whether the local governments (departments and communes) and certain public establishments were liable equally with the State for damages resulting from faults of service committed by their agents and employés. After

${ }^{\text {"s }}$ See the statistics given by Jacquelin, op. cit. 128. It was always refused. says Cot (La Responsabilite Civile des Functionnaires publics [1922] 58) when the functionary merely executed the orders of his superior. But Berthélemy, op. cit. 75 , points out that the immunity of the agent from prosecution did not cover his personal acts. As to the reasons for the rule see Hauriou, op. cit. 367; Berthélemy, op. cit. 78-79 and Cot, op. cit. ch. 2.

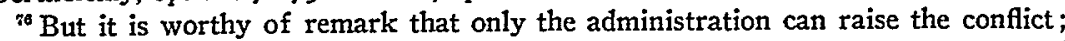
that is, it may prevent the judicial courts from encroaching upon the domain of the administration, but the judicial courts cannot by raising the conflict prevent the administration from encroaching upon their domain. See the criticism of Jacque in, op. cit. $5^{8}$.

${ }^{77}$ Jèze thinks that this jurisprudence is contrary to the law of 1870 which. intended to remove all barriers to the prosecution of administrative functionaries. (Op. cit. 102.) Jacquelin (op. cit. 132) holds the same opinion. But Cot (op. cit. $89-91$ ) and Hauriou ( $o p$. cit. 369) defend the interpretation which has been adopted. If the former view of the intent of the law of 1870 had been adopted the separation between "administration" and "justice," established at the time of the Revolution, would have disappeared and the judicial courts would have been left in full control of the administration. Now the tribunal of conflicts took the view that the law of 1870 never intended to impair the sacrosanct theory of the separation of powers. Whatever may be the facts as to this, the rule was definitely settled by the Pelletier case (1872) that the judicial courts are competent to hear only cases involving the personal acts of functionaries. 
long hesitation the tribunal of conflicts in the Feutry case in Igo8 reached the conclusion that they were.

For a long time, however, the council of state, following the doctrine of Laferrière, ${ }^{78}$ made a distinction between so-called actes d'autorité (or actes de puissance publique), and actes de gestion. The former embraced acts of command or prohibition and were considered to be "emanations" of sovereignty. The latter were managerial acts such as are involved in the operation of public utility services, the construction of public works, the operation of railroads, the postal service, telegraphs, telephones, etc. ${ }^{79}$ They are analogous to the acts of private individuals in the administration of their patrimony or in the management of business undertakings. Now it was felt that the State ought not to be held liable in damages for injuries sustained in consequence of acts of the former character, although it was admitted that such acts might be annulled for excess of power. As to managerial acts, however, the council of state took a different view and decided that the State might properly be held liable for damages resulting from faults of service in the performance of such acts and it regularly entertained jurisdiction of damage suits and condemned the State when faults of service were proven. From the first, however, the distinction between the two classes of acts was criticised by many jurists who maintained that the State should be held liable in both cases. The distinction, it was said, was vague, arbitrary and inconsistent with the established French doctrine of the liability of the State for faults of service committed by its agents. ${ }^{80}$ The council of state, however, hesitated to abandon its ancient doctrine and as late as 1899 in the Lepreux case it affirmed the existence of the principle. But the criticism of Hauriou and others was not without effect and in 1905 in the case of Tomaso Greco and later in the Feutry case (1908) it appears to have admitted that the distinction was not well founded. ${ }^{81}$ In consequence, the

\footnotetext{
I op. cit. 17 .

"Compare Berthélemy, op. cit. 43; Couzinet, op. cit. 36 and I Laferrière, op. cit. 436 .

su Such was the view of Duguit, Transformations, 155, 166; Jèze, Principes Généraux, 24; Hauriou, note on the Lepreux case of 1899 (Sirey, 1900, 3, I) ; Baumgart, op. cit. 57-58; and Cot, op. cit. 235 ff. Baumgart (op. cit. 58, note I), however, thinks that there are cases in which the irresponsibility of the State for so called actes de puissance publique is justified.

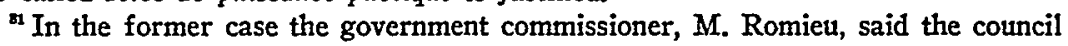
of state had come to recognize the "inconveniences, the contradictions and the iniquitous consequences" of the distinction. Quoted by Duguit, Transformations, 259-260. In the latter case the government commissioner, Tessier, declared that the distinction had no legal basis, that it did not correspond to the realities and that in truth there were no actes de puissance publique distinct from actes de gestion. Berthélemy (op. cit. supra note xg [9th ed. I920] 44-46) appears to be one of the few French jurists who uphold the former distinction although he admits that the State may be held liable on grounds of equity.
} 
responsibility of the State for damages resulting from its faults of service regardless of whether the acts causing them are acts of "authority" or of "management," is now generally admitted.

X

DISTINCTION BETWEEN FAULTS OF SERVICE AND PERSONAL FAULTS

The responsibility of the State is not yet, however, fully complete. It is still a principle of French administrative jurisprudence that the liability of the State, the department and the commune for damages, extends only to those resulting from faults of service, and not to those due to the personal faults of the functionary or agent. In the latter case the functionary or agent is personally responsible and the remedy of the plaintiff is a damage suit in a civil court against the official causing the damage. This principle was definitely established by a decision of the tribunal of conflicts in 1872 in the Pelletier case. ${ }^{82}$ Now the distinction between acts of service and personal acts is by no means clear. $^{83}$ Laferrière's doctrine ${ }^{84}$ that the distinction is that between an impersonal and a personal act is too vague for practical purposes. Hauriou's theory ${ }^{85}$ that a personal act is one which is detachable from the official function has found more favor and it has been approved by the tribunal of conflicts and the court of cassation. But cases are not lacking in which this criterion was impracticable of application. ${ }^{80}$

The principle on which the distinction is based is that if functionaries were personally liable for their faults of service they would show a timidity and hesitation which would affect injuriously the functioning of the administration. On the other hand, if they were absolutely irresponsible the public would be at their mercy. The French solution represents a compromise by which they are held liable for their personal faults while the State assumes responsibility for their official acts. Compare Nesmes-Des Marets, op. cit. 50-52.

${ }^{3}$ It is hardly necessary to remark that not every act of service is a fault of service nor every personal act a personal fault. In fact the two are frequently confused.

I op. cit. 648.

${ }^{8}$ Op. cit. $37 \mathrm{I}$.

so Thus the tribunal of conflicts has decided that the act of a mayor in ordering the ringing of church bells on the occasion of a funeral was a personal act, although it is difficult to see how the act was detachable from his official function. See the examples of personal acts mentioned by Hauriou, op. cit. 372, note I. Nearly every French writer has suggested a criterion of his own. For Michoud's theory, see his La Responsabilité Morale (Ig06) vol. I, sec. 64; for Cot's, see his work cited supra note 75, part II, chs. I-3; for Duguit's, see his Transformations. 273; for Berthélemy's, see his op. cit. 75 ; for Jèze's, see 26 R. D. P. 267 ff. According to Jèze there is a personal fault when the act reveals a mauvaise volonté and when the fault is a serious one (lourde) and it is serious when there is a gross error of judgment as to the fault. The tribunal of conflicts has approved this doctrine (case of Mascaras, I902) but there have been cases in which the agent was held personally liable when the fault was not lourde and where there was no mauvaise volonté. The various theories of personal fault are examined by Nesmes-Des Marets, De la Responsabilité Civile des Functionnaires, I64 fi. See 
Clearly there are cases in which an element of personal fault may exist in an act of service and there are also cases in which the two may coexist and the damage may be due to both. ${ }^{87}$ In such cases the injured individual has two remedies: ${ }^{88}$ (I) he may bring a personal damage suit in the civil courts against the agent; and (2) he may sue the State in an administrative court, ordinarily the council of state. There is thus a coëxistence of actions. Is there also a cumulation of liability? For a long time the principle of cumulation of responsibility was not admitted. The injured individual was allowed to sue the agent if he was personally responsible or the State if it was responsible, but he could not sue both. But this rule has been abandoned. There have been many cases in recent years in which the judicial court found the agent guilty of a personal fault and condemned him to pay damages while the council of state found a fault of service in the same case and condemned the State to pay damages. Here there was undoubtedly a cumulation of liability, that is, the establishment of the personal liability of the agent did not exclude the liability of the State. Would there also be a cumulation of indemnities so that the plaintiff might recover from both the State and the agent more than the actual amount of his damages? A famous case was that of Anguet (IgII) where an individual, finding himself in a postoffice after the public exit had been closed before the hour fixed by the regulations, was set upon and beaten by two employés of the postoffice while endeavoring to leave through a private exit. There was a personal fault on the part of the employés who attacked the plaintiff and they were condemned by the judicial court to pay damages. But this did not prevent the council of state from condemning the State to pay damages for the fault of service involved in closing the public exit in advance of the hour fixed by the regulations. ${ }^{80}$

also Soudat, Traité de la Responsabilité (6th ed. IgII) sec. 1356 and Dupeyroux, Faute personnelle et Faute du Service public (1922).

"Such were the cases of Anguet and Lhuillier described below.

It will be seen that the cumulation of liability results from the mutual independence of the judicial and administrative courts and the existence of a disagreement between them as to the nature of the fault. It is only when the judicial courts find that the fault is personal and the council of state finds it is a fault of service that there can be a cumulation of responsibility. This situation could only be avoided by the establishment of a common supreme court over both the administrative and judicial courts with the final power of decision as to the nature of the fault.

- See also the similar cases of Beaudelet (I915) and of Lemonnier (19r8) where there was a cumulation of actions and of liability. In the latter case, which has become famous, the mayor of a commune was condemned by the judicial court to indemnify an individual who had sustained an injury through a personal fault of the mayor in the management of a fête, while the commune was held responsible by the council of state which attributed the injury to a fault of service. For a good account of this case see Jèze's note, 36 R. D. P. $4 \mathrm{I}$ ff. See also the case of Lhuillier (1919) where the State was held liable in damages for the purely personal act of a drunken soldier who murdered a member of a family with whom he was quartered. The council of state, however, maintained that there was a fault of 
But while admitting a cumulation of personal and State liability in such cases the council of state took care not to admit the right of the plaintiff to a greater indemnity than what was sufficient to cover his damages. In the Babouet case it laid down the rule that the liability of the State was limited to the payment of only that part of the indemnity which by reason of his insolvency the agent was unable to pay; that is the responsibility of the State was subsidiary. But in the Lemonnier case the council of state adopted the principle of subrogation, that is, the State was condemned to pay the total amount of damages awarded with a reservation of its right to recover from the agent. ${ }^{90}$ The view of the council of state is that in the absence of some such rule the victim would be unable to collect the damages awarded, as in cases where the agent was insolvent.

\section{$\mathrm{XI}$}

LIABILITY OF THE STATE FOR PERSONAL FAULTS OF ITS AGENTS

Some French jurists have interpreted the recent jurisprudence of the council of state relative to the cumulation of personal and official liability as marking a virtual abandonment of the theory of fault of service as the basis of State liability for damages to private individuals and the substitution of the principle of risk responsibility; that is, the abandonment of the distinction between personal acts and acts of service and the admission of the liability of the State for damages resulting from both classes of acts without distinction. They maintain that the change should be made because the distinction between the two classes of acts is subtle and often impossible of application, ${ }^{91}$ and that to compel the injured individual to look to the agent for reparation in case the damage resulted from the latter's personal fault would in many cases, as

service which consisted in the absence of proper surveillance. Likewise in a series of cases involving damages caused by the construction of public works and the non-performance of contracts the council of state has admitted the principle of cumulation of responsibility. See Cot, op. cit. $293 \mathrm{ff}$ and Fliniatux, art. cited at pp. $345 \mathrm{ff}$. and the cases there cited.

${ }^{20}$ See Hauriou, op. cit. 380; Cot, op. cit. $298 \mathrm{ff}$, and Fliniaux, art. cited at pp. 349 ff. Hauriou criticizes the rule of subrogation for the reason that the administration may decline to compel the agent to make the reimbursement and hence the principle of personal responsibility will tend to disappear. Cot (op. cit. 30\%) is also of the opinion that the principle of cumulation of responsibility will have the effect of greatly extending the responsibility of the State and of diminishing correspondingly the personal liability of agents. Duguit thinks the council of state exceeded its power in holding that the State has a right to recover from the agent in such cases the amount of the indemnity paid by it. The jurisdiction of the council, he says, is limited to deciding whether there was a fault of service and whether therefore the State is liable to pay damages.

"See the criticism of Jacquelin, op. cit. 136. One French writer (Auger, Le Tribunal des Conflits sous la Deuxieme République [IgII] 200) remarks that in appearance the distinction is logical and even legitimate, but that in practice it is purely arbitrary and sometimes leads to contradictory results. 
English and American experience proves, leave him without an effective remedy. Professor Jèze in Igog predicted that in the near future the council of state would adopt this view. He based his prediction on a decision of the council of state made in February of that year in which it affirmed the responsibility of the State for damages sustained by a company through the personal fault of an administrative agent. ${ }^{22}$ When this decision was followed a few years later by others reaffirming this principle Professor Jèze was able to say that his prediction had come true. ${ }^{93}$ In these cases the council of state, to be sure, based its decision theoretically on the existence of a fault of service but in reality. it was the personal fault of the agent that had caused the damage. ${ }^{94}$ Whatever may be the facts as to this controverted question all French writers admit that the tendency of the jurisprudence of the council of state and of the tribunal of conflicts in these last years has been in the direction of admitting the liability of the State for all damages resulting from the faults of its agents without distinction as to whether they are personal faults or faults of service.95 Thus it has condemned the State to indemnify an individual who was accidentally shot by a policeman while pursuing an infuriated bull, although there was no fault of

"27 R. D. P. 76-77. Case of La Compagnie Commerciale de Colonisation du Congo Français, Dalloz, I9ro, 3, III.

${ }^{93}$ See his notes in 3I R. D. P. $569 \mathrm{ff} ; 33$ ibid. $378 \mathrm{ff} ; 36$ ibid. $4 \mathrm{I}$ ff.

'4 Fliniaux, Le Cumul de la Responsabilité de l'agent et de la Responsabilité de la personne morale administrative (I921) 38 R. D. P. 340; Duguit, La Question de la Coexistence des Responsabilités (r923) 40 R. D. P. 26 ff; Hauriou (op. cit. 380 ) ; Cot (op. cit. 282, 287) and others, however, do not think that these decisions justify Jèze's conclusions. Duguit maintains that there was in fact no cumulation of responsibility but merely a parallelism of responsibilities and that the council of state never held that the State was liable for the personal faults of its agents. True the judicial courts held that there was personal fault, but the council of state is not bound by the decisions of the judicial courts. Even if there existed personal fault, it was not for it but for the fault of service which coexisted with it that the council of state held the State to be liable. There is not a single case, Duguit maintains, in which the council of state ever condemned the State to pay damages on account of the personal fault of an agent. On the contrary, there are decisions in which the liability of the State in such cases was expressly denied. M. Duguit's article contains a luminous and up-to-date discussion of the whole question of coëxistence of personal and official liability. See also the bibliography on p. 40.

${ }^{25}$ Compare the conclusions of Fliniaux, 38 R. D. P. 356. It may be remarked in this connection that the council of state has shown an increasing disposition to construe strictly the notion of personal acts and whenever possible to attribute the damage to an act of service. Thus in the beginning it considered such acts as the delivery by a postman of a letter to a wrong address as a personal act, but in late years it has treated them as faults of service for which the State was held liable. See the cases cited by Hauriou, op. cit. 373. Note also the remarks of Duguit, Transformations, 26I, and his discussion of the Turpin case, p. 266 . Recent decisions have also revealed a tendency not to condemn agents for their personal faults unless they were serious (lourde). 
service.90 Likewise, following the close of the World War, the council of state condemned the State to pay damages in a large number of cases to individuals who had been injured by the explosion of shells that had been collected by the public authorities in various places, although it was impossible in many cases to impute any fault of service to the State. ${ }^{97}$ It may be remarked that in exactly identical cases occurring before the war the council of state had refused to condemn the State.98

The inevitable effect of the new jurisprudence must be to diminish very greatly the personal responsibility of administrative agents. Hauriou goes to the length of predicting that in a few years there will be no prosecution of functionaries for their personal acts because the State will be liable and the injured individual can obtain his reparation more easily and certainly by suing the State. ${ }^{99}$ The effect of the progressive disappearance of the responsibility of functionaries upon their character has not been overlooked by French writers. ${ }^{100}$ Fault as the basis of the State's responsibility is finding an increasing number of combatants who demand the substitution of the theory of risk responsibility. Duguit, one of the most eminent of them, affirms that the State cannot commit faults. It should be responsible for all damages committed by its agents whether there is an alleged fault of service or not. ${ }^{101}$ The acceptance of this doctrine, which now seems quite probable, will, as Hauriou remarks, make the State an insurance society against all damages resulting from its acts. ${ }^{102}$ Hauriou and others have pointed out that the new doctrine, if accepted without qualification, will entail a heavy responsibility for the State and will not be without serious danger. ${ }^{103}$

\footnotetext{
Case of Tomaso Greco. See also the case of Pluchard (1909) where damages were awarded an individual for being run over by a policeman although there was no fault of service on his part.

${ }^{\prime \prime}$ See the cases cited by Cot, op. cit. $238 \mathrm{ff}$, especially that of Regnault-Desroziers (1918).

${ }^{88}$ While the decisions in the post war explosion cases undoubtedly marked a reversion of the jurisprudence of the council of state, some French writers do not think it justifies the conclusion that the council of state has definitely abandoned the distinction between personal faults and faults of service. Cot (op. cit. 242) argues that the circumstances under which the new rule was applied in the recent cases were entirely exceptional and that it has not in fact been followed since Ig20.

${ }^{\circ}$ See his note in the Lemonnier case, cited above. Compare also Cot, op. cit. 3I5, 324.

${ }^{10}$ Compare Cot, op. cit. 316 , who remarks that an entirely irresponsible functionary will be the worst possible functionary. To the same effect see also the opinion of Jacquelin, op. cit. I24.

${ }^{101}$ Transformations, 250. But he does not favor the personal irresponsibility of the agent. The State is not and cannot, he says, be responsible for the faults of the agent when they are his personal acts entirely separable from the public service. See his article cited, at p. 39.

${ }^{100}$ See his note on the Regnault-Desroziers case, Sirey, I918-19, at p. 26.

${ }^{100}$ See his note cited above p. 25 ; also Cot, op. cit. 244 and Fliniaux, 38 R. D. P. 356 , note 4 .
} 


\section{XII}

\section{CONCLUDING OBSERVATIONS}

Such in outline are the dominant principles of the French droit administratif in its present state of development. In the beginning, its chief purpose was to protect the administration against interference on the part of the judicial magistrates, but in the course of its development it has become a system of law whose principal object is to protect private individuals against the arbitrary and illegal conduct of the administrative authorities and to insure reparation to those who have suffered injuries on account of the faults of those authorities. The degree of protection which it provides and the certainty of reparation which it assures are distinctly greater than that which is afforded by the law of any other country. It is to the council of state that this situation is mainly due. For a long time the judicial courts were considered to be the guardians of private rights, but this rôle has largely passed to the council of state. ${ }^{104}$ With an expenditure of only I2 sous and without the necessity of employing an attorney, almost any citizen can now go to the council of state and secure the annulment of any illegal act (with a few trifling exceptions) of any administrative authority, whether it be that of the President of the Republic or a village mayor. The congested dockets of the council and the thousands of cases which it handles every year afford evidence enough of its popularity. ${ }^{105}$ The number of cases submitted to it has grown rapidly. From I902 to I9I3 the number increased from 3, II 3 to $4,273 .{ }^{108}$ In recent years the flow has reached such volume that the council is hopelessly in arrears with its work ${ }^{107}$ and the Parliament is confronted with the problem of how to alleviate the situation..$^{108}$

\footnotetext{
${ }^{104}$ Compare Idoux, La Jurisprudence du Conseil d'Etat et de la Cour de Cassation Quant aux Points qui leur sont Communs (Ig08) II, 44.

${ }^{100}$ I have before me the calendar of the council for the 8th and gth of March, 19r2. It includes 37 cases, embracing actions for the annulment of many ordinances of mayors, prefects, ministers and even of the President of the Republic; of decisions of educational authorities; ordinances of the Residents-general and governors of various colonies; the decisions of various councils of prefecture and of departments; of commissions and councils of discipline; of the rector of the University of Alger; etc.

${ }^{100}$ See the statistics in 35 R. D. P. $509 \mathrm{ff}$.

${ }^{107}$ On the I5th of August, I9I7, there were 7,125 cases on its dockets. By the I5th of August, 1919, however, the arrears had been reduced to 5,664. 37 R. D. P. 555. The work of the council was naturally increased during the war.

${ }_{105}$ Various suggestions have been made with this end in view. The two most important are: the creation of special regional administrative courts with final jurisdietion save the right of recourse in cassation to the council of state, and the transfer to the judicial courts of a portion of the contentient administratif. Regarding the subject see two valuable articles entitled La. Réforme de la Jurisdiction Administrative, by Monsieur J. Laferrière, in (1920) 37 R. D. P. 353 ff and (I92I) 38 ibid. Iog ff. See also Cot, op. cit. 306 , who remarks that in consequence of the crowded calendars of the council of state suitors can now get quicker action
} 
There are a few in France who criticize the whole system of administrative jurisdiction and maintain that it should be handed over to the ordinary judicial courts as in England and the United States, ${ }^{109}$ but the existing system is approved and defended by the vast majority of French writers and jurists and all attacks against it have so far proved futile. There is little or no feeling in France that the system unduly protects the official class, that by subjecting functionaries and private individuals to a different law the latter are placed on a footing of inequality, that the administrative courts are the servile instruments of the government, and the like. The belief of English and American critics that the members of the council of state, being removable at the pleasure of the government, do not feel free to decide important cases against it, has no real basis. In fact, no member has ever been removed or threatened with removal since the establishment of the third Republic, nor is there any instance in which improper pressure was ever brought by the government against any member to influence his decision. ${ }^{110}$ Public opinion today would not tolerate such interference and there is no likelihood that it will ever again be resorted to. The hundreds of decisions nullifying the acts of the government and condemning it to pay damages for its wrongful acts is, in itself, a sufficient refutation of the charge that the council of state lacks independence. Indeed, it has been criticized by some Frenchmen for showing an excessive bias against the government and in favor of private individuals; that it has given more consideration to equity and less to law than should have been done. It is in this respect that its jurisprudence differs essentially from that of the court of cassation. If an American may venture to criticize its jurisprudence he would say that it has been too progressive. Whenever a long established rule has been found to stand in the way of the protection and reparation which in the opinion of the council the

in the judicial courts. Generally, however, the remedy is an action before the council of state and in any case suitors prefer the latter tribunal because it is well known to be more favorable to private individuals than is the court of cassation.

${ }^{100}$ For example, Jacquelin, $o p$. cit. I07 ff, and Dareste cited by Couzinet, op. cit. 19r. M. Saget argued in the chamber of deputies on July 5, r920 that the system of administrative jurisdiction should be abolished and the contentieux administratif transferred to the judicial courts. "Justice rendered in the name of the French people," he said, "should not have two faces; we wish it to be one and independent. We think that the judicial courts alone, by reason of the irremovability of the judges and their method of appointment, are capable of giving sufficient guarantees to suitors, the guarantees to which they have a right." Quoted by J. Laferrière, 37 R. D. P. 553, note I.

${ }^{110}$ Members of the council of state have assured me that there is absolutely no foundation for the belief in England and America that the council is not entirely independent of all government control or pressure. Dicey, the most redoubtable critic of the French droit administratif, virtually admitted in the last edition of his Law of the Constitution (7th ed. 1908) that he had misunderstood it and that he had relied too much upon de Tocqueville whose ignorance of the subject was well known. See his preface to the seventh edition; also p. 327. 
individual was entitled to, it has not hesitated to reverse itself and establish a new principle. But generally these revirements of jurisprudence have been in response to the teachings of the jurists and the demands of public opinion.

As regards the responsibility of the State for damages done through the faults of its agents the council of state has gone to extreme lengths. The dominating principle of the new jurisprudence is that the liability of the State should be the same as that of a private employer of labor, that this liability should cover every injury resulting from a fault of service and that the reparation due should be made by the State rather than shifted to the personal shoulders of the agent. As stated above, the recent decisions indicate that the council may soon go still further and lay down the rule that the State shall be liable for injuries resulting from any and every administrative act whether there is fault or not. In short, the State shall assume the risk and become the virtual insurer of its citizens against all damages resulting from its acts. The principle of State liability has been carried to such lengths in recent years that the responsibility of functionaries for their personal faults has been greatly reduced and is tending more and more to disappear. But in general, the new jurisprudence is approved by the French public, who believe that considerations of justice require that the State should assume full responsibility for all damages caused by its agents and indemnify the victims thereof.

A remarkable feature of the French administrative law which has thus brought under the control of the council of state the entire administrative personnel, both central and local, from the President down to the pettiest functionary, and which has subjected the. State to a liability now almost absolute, is that it has been done in the main by the decisions of the council of state itself. The Parliament could at any time have intervened and have prevented by legislation this extraordinary extension of judicial control and of State liability; it could have regulated both and have fixed the limits of each, but it has not chosen to do so. On the conirary, it has left the development of the law entirely to the tribunals (mainly the council of state), without interference or restriction of any kind, and has thus by acquiescence approved the jurisprudence which they have built up. Altogether it is a remarkable testimonial on the part of the legislature of its confidence in the administrative tribunals. 